\title{
Health insurance literacy: discussion and reaction of Facebook users' towards the National Health Insurance in Indonesia
}

\author{
Tika Indiraswari, ${ }^{1,2}$ Stefanus Supriyanto, ${ }^{3}$ Ernawaty Ernawaty, ${ }^{3}$ Nuzulul Kusuma Putri ${ }^{3}$ \\ ${ }^{1}$ Doctoral Program of Public Health, Universitas Airlangga, Surabaya; ${ }^{2}$ Faculty of Public Health, Universitas \\ Serambi Mekkah, Banda Aceh; ${ }^{3}$ Department of Health Policy and Administration, Faculty of Public Health, \\ Universitas Airlangga, Surabaya, Indonesia
}

\begin{abstract}
Universal Health Coverage always persevered as a pro poor policy in many countries, characterized by a major impact on higher out-of-pocket healthcare costs, with low-cost alternative prescription drugs and capitation payments made to physicians, in order to reduce inequity. These concerns have been discussed widely on social media, including Facebook, but social media are consistently neglected as a source of scientific information. The purpose of this study, therefore, is to analyze the thought process or feelings of individuals about the policies, also focusing on the possible reactions. Hence, a systematic review in the form of discussion forums on the Facebook page of the National Health Insurance Agency, Indonesia was conducted from 2015 to 2016, with regards to the implementation of National Health Insurance, within a year and half after the policy was launched. In addition, the contents of 148 discussions were deductively analyzed, and the findings showed the pragmatic disposition of most Facebook users towards health care utilization, the costs of Insurance, and the possible benefits of payment. Furthermore, the debate conducted in social media related with the policy and its practice issues ought to be countered through appropriate modification.
\end{abstract}

\section{Introduction}

Universal Health Coverage frequently persisted as a pro poor policy in numerous countries, which ensures the provision of better access and quality of personal health services to the poor. This agenda has been achieved through the implementation of National Health Insurance (NHI) policies in Indonesia from 2014, which was organized by the Indonesian Social Security Agency for Health (SSAH). Currently, the coverage extends to about 222.5 million people, involving a comprehensive program, based on membership levels (first-class, second-class or third-class facilities) in an extensive integrated care, consisting of continuous, reachable and equitable access to health services. ${ }^{1-3}$
Previous study reported on the significant correlation between patient satisfaction and payment for premium NHI, in both primary care centers and hospitals. This brought a feeling of satisfaction with the quality of services to over three-fourth $(79.7 \%)$ of users in primary care, and $81.1 \%$ of were gratified in hospitals. ${ }^{4}$ Despite the positive perception, poor people are unable to pay the commended fees, leading to the provision of inadequate health budget and care services. Meanwhile, the poor literacy on the subject of health insurance is associated with the tendency for people to avoid healthcare services, subsequently worsening the health status, and increasing the economic burden. Studies showed the provision of delayed or improper care to over half of the population not using health insurance and poor literacy prevent individuals from obtaining preventive and non-preventive services. 5,6

Rather than reducing inequities, this policy majorly influences an increase in out-of-pocket healthcare costs, low-cost alternative prescription drugs and capitation payments made to physician. ${ }^{7}$ Meanwhile, equity in the access and quality of health services ought to be increased by providing accurate interventions, improving health management and the proper organization of both public and private health sector, targeting particularly the rural areas. ${ }^{8}$ There is a need to consider the design of the health system, in order to enhance the need to track health coverage, socialize benefits and improve the effectiveness of care provided. Hence, the $\mathrm{NHI}$ is expected to encourage people to develop healthy lifestyles, consequently preventing illness, particularly for chronic diseases. The provision of sufficient funding was planned to facilitate maternity care, hygiene, children health, tobacco use and healthy lifestyle. Meanwhile, it is also possible to properly manage health promotion and prevention if policymakers and politicians develop and foster good environments and lifestyles. ${ }^{9-11}$

Social media has been incorporated for the communication of health strategies, through the form of discussions related to National Health Insurance policies. This provides a wide range of benefits and opportunities required to improve literacy in a variety of ways, as the medium plays a vital role in information sharing, deliberations on potential benefits, resolving health related issues, promoting hygienic behaviors, as well as providing help to indi-

Significance for public health

Social media has been incorporated for the communication of health strategies in Indonesia, through the discussions related to National Health Insurance policies. Social media can provide opportunities to better understand the concept of health insurance literacy and facilitate growth in social norms and skills, as participants of online forums. Until now, there is a deficiency in studies related to the use of social media as source of news where people pay attention to specific issues. This study analyzes the thought process and feelings of individuals, as well as the reaction towards the National Health Policies implemented. 
viduals and communities, related to the state of health. In addition, it is possible to adopt social media in the development of discussion skills, in both local and global context, subsequently providing opportunities to better understand the concept of health insurance literacy and facilitate growth in social norms and skills. ${ }^{12-14}$

Universal health coverage ensures the access to health services without the fear of healthcare costs amongst the population of a country. This is offered to each individual by the government, regardless of the ability to pay for premium insurance. Thia has been discussed widely on social media, including Facebook, although the adoption of social media as sources of scientific information is neglected. Furthermore, issues related to the implementation of NHI were previously studied, and almost half of the citizens were reported to have no health coverage, as the desire to pay for health services is not fulfilled, due to the less benefits received. These include the reduced accuracy in patient care, overcrowding and longer wait times, as well as limited resources, in terms of health professionals. ${ }^{15,16}$ There is a deficiency in studies related to the use of social media as an important source of news, where people pay attention to specific issues. Thus, this investigation aims to analyze the thought process and feelings of individuals, as well as the reaction towards the implemented health policies.

\section{Design and methods}

This was a systematic review of discussion forums on the Facebook page of the National Health Insurance Agency, Indonesia regarding the implementation of the National Health Insurance, which conducted from 2015 to 2016, just a year and half after the launch of these policies. Furthermore, the content of 148 discussions were deductively evaluated, followed by the analysis of data collected, using SPSS 22.0.

\section{Results and discussion}

The aim of this study is to identify the discussion and reaction of Facebook user's towards the National Health Insurance policy in Indonesia. The findings showed the pragmatic disposition of most respondents regarding healthcare utility and costs of Insurance, as well as the possible benefits obtained after making payment. Table 1 shows the descriptive statistics of discussion topics on Facebook page, which demonstrated an increase in interest (more Likes) in more negative posts. Table 2 indicates the heightened curiosity of most respondents regarding the procedures for payment, and also for clarity on the benefit obtained from being NHI member.

Based on the Chi-square analysis result, a relationship was established between the number of news related to Universal Health Insurance, the cumulative likes, total super reaction, and the impact comment on NHI, with a $\mathrm{P}<0.05$ (Table 3 ).

Facebook is used to share thoughts, seek information, and share stories regarding daily experiences, including the use of healthcare and health insurance. Furthermore, demographic factors, consisting of age, living areas, history of illness, economic status and proper education level had significant correlation with independent NHI membership, where living areas was identified as the most dominant variable with a value of $\operatorname{Exp}(B)=7.03$, after the control of others. Meanwhile, an encouragement for membership ought to be initiated in regions with low participation rates, which is attainable by enhancing health insurance promotion, socializing and educating on the registration process, as well as the potentially achievable benefits. ${ }^{18,19}$

The social media is often used to develop social networking, provide education based on health practices as well as the promotion of wholesome behaviors. The use of Facebook for online discussions influences the ability of individuals to address NHI issues in a meaningful way. Hence, it is necessary for health professionals to participate actively through this medium, in order to overcome barriers. Furthermore, social media plays important roles as a source of information, which helps people at all membership stages and on each step, because people need adequate knowledge to properly conduct all related activities. ${ }^{20,21}$

Through social media, health professionals are empowered by the ability to share relevant health issues, receive feedback, and build patient trust. However, it is important to recognize the fact

Table 1. Descriptive statistics of discussion topic on Facebook.

\begin{tabular}{|c|c|c|c|c|}
\hline Discussion Topic & negative & $\begin{array}{c}\text { D } \\
\text { neutral }\end{array}$ & positive & Total \\
\hline Registration procedure & $\begin{array}{c}1 \\
1.8 \%\end{array}$ & $\begin{array}{c}54 \\
98.2 \%\end{array}$ & $\begin{array}{c}0 \\
0.0 \%\end{array}$ & $\begin{array}{c}55 \\
100.0 \%\end{array}$ \\
\hline Premium payment procedure & $\begin{array}{c}1 \\
5.0 \%\end{array}$ & $\begin{array}{c}19 \\
95.0 \%\end{array}$ & $\begin{array}{c}0 \\
0.0 \%\end{array}$ & $\begin{array}{c}20 \\
100.0 \%\end{array}$ \\
\hline Amount of premium payment & $\begin{array}{c}1 \\
16.7 \%\end{array}$ & $\begin{array}{c}4 \\
66.7 \%\end{array}$ & $\begin{array}{c}1 \\
16.7 \%\end{array}$ & $\begin{array}{c}6 \\
100.0 \%\end{array}$ \\
\hline Clarity of benefits & $\begin{array}{c}3 \\
7.3 \%\end{array}$ & $\begin{array}{c}37 \\
90.2 \%\end{array}$ & $\begin{array}{c}1 \\
2.4 \%\end{array}$ & $\begin{array}{c}41 \\
100.0 \%\end{array}$ \\
\hline Complete benefits & $\begin{array}{c}0 \\
0.0 \%\end{array}$ & $\begin{array}{c}0 \\
0.0 \%\end{array}$ & $\begin{array}{c}2 \\
100.0 \%\end{array}$ & $\begin{array}{c}2 \\
100.0 \%\end{array}$ \\
\hline Reference & $\begin{array}{c}4 \\
44.4 \%\end{array}$ & $\begin{array}{c}5 \\
55.6 \%\end{array}$ & $\begin{array}{c}0 \\
0.0 \%\end{array}$ & $\begin{array}{c}9 \\
100.0 \%\end{array}$ \\
\hline Indonesian Social Security Agency for Health (SSAH) Organization & $\begin{array}{c}1 \\
50.0 \%\end{array}$ & $\begin{array}{c}1 \\
50.0 \%\end{array}$ & $\begin{array}{c}0 \\
0.0 \%\end{array}$ & $\begin{array}{c}2 \\
100.0 \%\end{array}$ \\
\hline Indonesian Social Security Agency for Health (SSAH) relationship with health provider & $\begin{array}{c}1 \\
100.0 \%\end{array}$ & $\begin{array}{c}0 \\
0.0 \%\end{array}$ & $\begin{array}{c}0 \\
0.0 \%\end{array}$ & $\begin{array}{c}1 \\
100.0 \%\end{array}$ \\
\hline Other topics & $\begin{array}{c}1 \\
8.3 \%\end{array}$ & $\begin{array}{c}11 \\
91.7 \%\end{array}$ & $\begin{array}{c}0 \\
0.0 \%\end{array}$ & $\begin{array}{c}12 \\
100.0 \%\end{array}$ \\
\hline
\end{tabular}

Sig. $=0.000$. 
Table 2. Descriptive statistics of providing comments and emoticons on facebook

\begin{tabular}{lcc} 
Topics & Number of Comments & Number of Emoticon \\
Payment procedures & 439 & 263 \\
Clarity of benefits & 161 & 106 \\
\hline Indonesian Social Security Agency for Health (SSAH) & 82 & 23 \\
Insurance Premium & 39 & 191 \\
\hline Other topics & 37 & 34 \\
The relationship between Indonesian Social Security Agency for Health (SSAH) and health provider & 32 & 4 \\
\hline Referral & 0 & 27 \\
Complete benefits & 0 & 23 \\
\hline
\end{tabular}

Table 3. The results of chi-square analysis.

\begin{tabular}{lcccc} 
& The number of news & The number of likes & The number of super reaction & The impact comments on NHI \\
Chi-Square & $203.608^{\mathrm{a}}$ & $213.459^{\mathrm{b}}$ & $284.122^{\mathrm{a}}$ & $378.500^{\mathrm{c}}$ \\
df & 2 & 17 & 2 & 26 \\
\hline Asymp. Sig. & .000 & .000 & .000 & .000
\end{tabular}

${ }^{a} 0$ cells $(0.0 \%)$ have expected frequencies less than 5 . The minimum expected cell frequency is $49.3 .{ }^{\text {b }} 0$ cells $(0.0 \%)$ have expected frequencies less than 5 . The minimum expected cell frequency is 8.2 . ${ }^{0}$ cells $(0.0 \%)$ have expected frequencies less than 5 . The minimum expected cell frequency is 5.5 .

that online information is exposed to a wide range of content, ${ }^{22,23}$ as seen from the display of other topics on the list of the NHI Facebook page. Therefore, health professionals are expected to take cognizance of other potential risks, including poor information or breaches in professional boundaries and patient privacy, which possibly results in legal negligence. ${ }^{24-27}$

Due to barriers in the health systems, policy and political parties, numerous challenges and opportunities were faced in attempts to successfully improve the universal health coverage. In addition, a high level of political commitment is possibly attained by taking relevant actions in Indonesia before 2030. Meanwhile health system management requires strong, resilient, functional, integrated care, characterized by continuous, reachable and equitable access to health services, which is community-based, people-centered and supported by a competent health team with adequate policy frameworks, as well as granted by sustainable funding. ${ }^{11,15,28,29}$

The enhancement of health insurance systems comes with the rigorous challenges, extending from issues of membership to insurance claims, payment and also the processes for ensuring reimbursement. Furthermore, it is necessary to promote NHI membership, which subsequently presents strong opportunities to improve care, and also provide individual and community needs. Meanwhile it is essential that Government supports all stakeholders, ranging from the health system management to all staff, including doctors, nurses and administrators. ${ }^{30-33}$

\section{Conclusions}

Based on the results and discussion, this study showed the significant increase in negative reaction from Facebook users. Hence, the debates on issues related to the National Health Insurance policy and practice in social media ought to be countered by introducing the appropriate modifications.
Correspondence: Stefanus Supriyanto, Department of Health Policy and Administration, Faculty of Public Health, Universitas Airlangga, Jl. Mulyorejo, Surabaya, Jawa Timur 60115, Indonesia.

Tel.: +62315920948 - Fax: +62315924618

E-mail: stefpriyanto49@gmail.com.

Key words: National Health Insurance; utilization; policy; facebook users.

Contributions: The authors contributed equally. TI, SS, EE designed and directed the project, TI, NKP developed the theoretical framework and wrote the article.

Conflict of interests: The authors declare no potential conflict of interests.

Funding: This study was supported by Faculty of Public Health, Universitas Airlangga

Acknowledgments: The authors thank Faculty of Public Health, Universitas Airlangga that has provided invaluable support for the study.

Clinical trials: This research does not involve any clinical trials.

Conference presentation: Part of this paper was presented at the $4^{\text {th }}$ International Symposium of Public Health, 2019 October 29-31, Griffith University, Gold Coast, Australia.

Received for publication: 6 March 2020.

Accepted for publication: 13 June 2020.

Copyright: the Author(s), 2020

Licensee PAGEPress, Italy

Journal of Public Health Research 2020;9:1844

doi:10.4081/jphr.2020.1844

This work is licensed under a Creative Commons Attribution NonCommercial 4.0 License (CC BY-NC 4.0). 


\section{References}

1. Myint CY, Pavlova M, Thein KNN, et al. A systematic review of the health-financing mechanisms in the Association of Southeast Asian Nations countries and the People's Republic of China: Lessons for the move towards universal health coverage. PLoS One 2019:14:e0217278.

2. Mboi N. Indonesia: On the Way to Universal Health Care. Health Systems Reform 2015;1:91-7.

3. Ooms G, Kruja K. The integration of the global HIV/AIDS response into universal health coverage: desirable, perhaps possible, but far from easy. Global Health 2019:15:41.

4. Nurhasana R, Hidayat B, Pujiyanto, et al. Does JKN Member's Satisfaction on Healthcare Services Correlate with Sustainability of Premium Payment? Evidence from the Behavior of Self-Enrolled Member in Greater Jakarta Area. In: Susanna D, Sutomo S, Budiharsana MP, et al, eds. Proceedings of The 3rd International Meeting of Public Health and The 1st Young Scholar Symposium on Public Health; 2017 Sep 18-20; Universitas Indonesia; KnE Life Sciences 2019:302-310.

5. Tipirneni R, Politi MC, Kullgren JT, et al. Association Between Health Insurance Literacy and Avoidance of Health Care Services Owing to Cost. JAMA Network Open 2018;1:e184796.

6. Nisa' C, Sari IN. Social Health Insurance Literacy: Lesson Learned From Social Insurance For Maternity Care By National Health Insurance Programme. Jurnal Administrasi Kesehatan Indonesia 2019;7:25-32.

7. Chemouni B. The political path to universal health coverage: Power, ideas and community-based health insurance in Rwanda. World Dev 2018;106:87-98.

8. Mboi N, MurtySurbakti I, Trihandini I, et al. On the road to universal health care in Indonesia, 1990-2016: a systematic analysis for the Global Burden of Disease Study 2016. The Lancet 2018; 392:581-91.

9. Agustina R, Dartanto T, Sitompul R, et al. Universal health coverage in Indonesia: concept, progress, and challenges. The Lancet 2018;393:75-102.

10. Reich MR, Harris J, Ikegami N, et al. Moving towards universal health coverage: lessons from 11 country studies. The Lancet 2016;387:811-6.

11. Pisani E, Olivier Kok M, Nugroho K. Indonesia's road to universal health coverage: a political journey. Health Policy Plann 2016;32:267-76.

12. Ventola CL. Social media and health care professionals: benefits, risks, and best practices. PT 2014;39:491-520.

13. Alshakhs F, Alanzi T. The evolving role of social media in health-care delivery: measuring the perception of health-care professionals in Eastern Saudi Arabia. J Multidiscip Healthcare 2018;11:473-9.

14. Pentescu A, Cetină I, Orzan G. Social Media's Impact on Healthcare Services. Proced Econ Finance 2015;27:646-51.

15. Dartanto T, Halimatussadiah A, Rezki JF, et al. Why Do Informal Sector Workers Not Pay the Premium Regularly? Evidence from the National Health Insurance System in Indonesia. Appl Health Econ Health Policy 2020;18:81-96.
16. Tan SY, Qian J. An unintended consequence of provider payment reform: The case of capitation grants in the National Health Insurance reform of Indonesia. Int J Health Plann Manage 2019;34:e1688-10.

17. Sari B, Idris H. Determinant of Independent National Health Insurance Ownership in Indonesia. Malaysian J Pub Health Med 2019;19:109-15.

18. Ng JYS, Ramadani RV, Hendrawan D, et al. National Health Insurance Databases in Indonesia, Vietnam and the Philippines. PharmacoEcon Open 2019;3:517-26.

19. Wiseman V, Thabrany $\mathrm{H}$, Asante A, et al. An evaluation of health systems equity in Indonesia: study protocol. Int J Equity Health 2018;17:138.

20. Keller B, Labrique A, Jain KM, et al. Mind the Gap: Social Media Engagement by Public Health Researchers. J Med Internet Res 2014;16:e8.

21. Staccini P, Douali N. Social Media and Patient Health Outcomes. IMIA Yearbook 2014;9:195-8.

22. Lau AYS, Gabarron E, Fernandez-Luque L, et al. Social Media in Health-What are the Safety Concerns for Health Consumers? Health Inf Manag 2012;41:30-5.

23. Bhaskaran N, Kumar M, Janodia MD. Use of Social Media for Seeking Health Related Information-An Exploratory Study. J Young Pharm 2017;9:267-71.

24. Pillow M, Hopson L, Bond M, et al. Social Media Guidelines and Best Practices: Recommendations from the Council of Residency Directors Social Media Task Force. West J Emerg Med 2014;15:26-30.

25. Antheunis ML, Tates K, Nieboer TE. Patients' and health professionals' use of social media in health care: Motives, barriers and expectations. Patient Educ Couns 2013;92:426-31.

26. George DR. "Friending Facebook?" A Minicourse on the Use of Social Media by Health Professionals. J Contin Educ Health Prof 2011;31:215-9.

27. Li J. Privacy policies for health social networking sites. J Am Med Inform Ass 2013;2:704-7.

28. Greer SL, Méndez CA. Universal Health Coverage: A Political Struggle and Governance Challenge. Am J Public Health 2015;105:S637-9.

29. Fattore G, Tediosi F. The Importance of Values in Shaping How Health Systems Governance and Management Can Support Universal Health Coverage. Value Health 2013;16:S19-23.

30. McKee M, Balabanova D, Basu S, et al. Universal Health Coverage: A Quest for All Countries But under Threat in Some. Value Health 2013;16;S39-45.

31. Borgonovi E, Compagni A. Sustaining Universal Health Coverage: The Interaction of Social, Political, and Economic Sustainability. Value Health 2013;16:S34-8.

32. Tarricone R. Setting the Scene: The Challenges of Universal Health Coverage and the Contribution of Management Education. Value Health 2013;16:S4-S6.

33. Dieleman JL, Sadat N, Chang AY, et al. Trends in future health financing and coverage: future health spending and universal health coverage in 188 countries, 2016-40. The Lancet 2018;391:1783-98. 